УАК 616. 314.-018.4-002.4-07/-08

(CН. В.Чорній, А. В. Чорній, М. М. Фалінський

АВНЗ «Тернопільський державний медичний університет імені І. Я. Горбачевського»

\title{
Погляд на проблему розвитку, Аіагностики, лікування та профілактики комп'ютерного некрозу зубів
}

Резюме. У статті представлено огляд літератури з проблеми розвитку, діагностики, лікування та профілактики комп'ютерного некрозу зубів, що спостерігається у людей, робота яких пов'язана 3 багатогодинним перебуванням за комп'ютером протягом $2-3$ років.

Ключові слова: комп'ютерний некроз, захворювання пародонта, пероксидне окиснення ліпідів, антиоксидантний захист.

\section{Н. В. Чорний, А. В. Чорний, М. М. Фалинский}

ГВУЗ «Тернопольский государственный медицинский университет имени И. Я. Горбачевского»

\section{Взгляд на проблему развития, Аиагностики, лечения и профилактики компьютерного некроза зубов}

Резюме. В статье представлен обзор литературы по проблеме развития, диагностики, лечения и профилактики компьютерного некроза зубов, наблюдающегося у людей, работа которых связана с многочасовым пребыванием за компьютером в течение $2-3$ лет.

Ключевые слова: компьютерный некроз, заболевания пародонта, пероксидное окисление липидов, антиоксидантная защита.

\section{N. V. Chorniy, A. V. Chorniy, M. M. Falinskyy \\ SHEI «Ternopil State Medical University by I. Ya. Horbachevsky» \\ Look to the problem of development, diagnosis, treatment and prevention of computer necrosis of teeth}

Summary. This paper provides an overview of literature on the development, diagnosis, treatment and prevention of computer necrosis of teeth seen in people whose work involves long hours of staying at your computer for $2-3$ years.

Key words: computer necrosis, periodontal disease, lipid peroxidation, antioxidant protection.

За останні кілька років поширеність некаріозних уражень емалі значно зросла. Окремі автори пов' язують це із Чорнобильською катастрофою і погіршенням екологічної ситу- 
ації у цілому (П. М. Чорнобильська, 1993р; Ю. А. Федоров та співавт., 1996). У розвитку захворювання велике значення мають професійні шкідливості, несприятливі умови праці (Аля працюючих за комп'ютером), системні захворювання (захворювання ШКТ, остеохондроз, ревматизм та ін.), тривалий прийом саліцилатів і соляної кислоти, застосування контрацептивних засобів жінками молодого віку. Зростання числа захворювань проявляється розвитком ерозій, патологічним стиранням і некрозом емалі зубів $[1,5]$.

Проте в останні роки лікарі зіткнулися 3 дивовижним захворюванням зубів, яке, як правило, спостерігали у людей, які працюють за комп'ютером. Виник так званий комп'ютерний некроз зубів, пов'язаний із багатогодинною роботою за комп'ютером протягом $2-3$ років $[3,7]$.

Відомо, що сучасні комп'ютери мають м'яке іонізуюче випромінювання, створюють особливе електромагнітне поле, дають електростатичну дію і впливають на резистентність організму в цілому. Іонізуюче випромінювання призводить до іонізації молекул і атомів, утворюючи вільні радикали, пероксидні сполуки, що спричиняють порушення функції клітин, їх біохімічні процеси та призводять до загибелі окремих клітин зуба. Антиоксидантних резервів, буферних систем може виявитися недостатньо Аля збереження окисного гомеостазу, особливо при дефіциті надхоАження антиоксидантів в організм $[4,10]$.

Некроз мінералізованих тканин пов'язаний із частковою загибеллю одонтобластів або різким порушенням їх та інших життевих елементів пульпи, а також із безпосередньою дією проникаючого випромінювання та інших факторів на білкові структури емалі та дентину, що викликають у кінцевому рахунку некроз тканин зуба. Важливим негативним чинником $є$ також порушення функції слинних залоз, що призводить до погіршення процесів фізіологічної ремінералізації емалі [6, 9].

Відбувається втрата блиску і руйнування емалі. Множинні «мертві» місця на емалі мають темно-коричневий колір. Вогнища некрозу охоплюють значну або навіть більшу частину коронок зубів, насамперед імунної, Аля карієсу поверхні. Це пришийкова їх частина, корені зубів і альвеолярна кістка.
Ураження в основному пігментовані - від солом'яного до темно-коричневого, заповнені розм'якшеним дентином. Вони легко видаляються екскаватором; як правило, безболісні. Зуби втрачають живий блиск. Ураження характеризується системністю та множинністю (рис. 1-3).

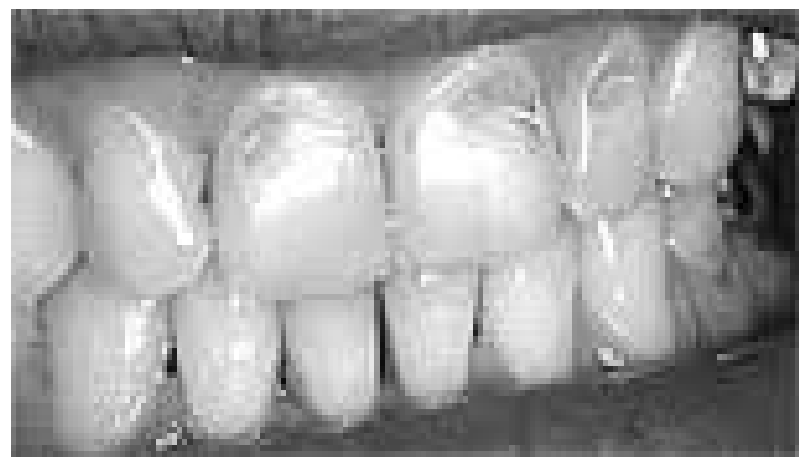

Рис. 1. Вогнища некрозу розміщені у пришийковій зоні центральних та латеральних різців верхньої щелепи.

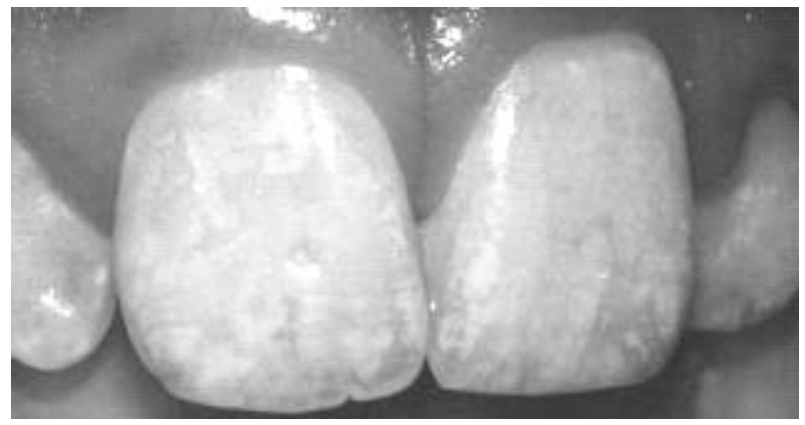

Рис. 2. Втрата блиску та руйнування емалі центральних та латеральних різців на верхній щелепі.

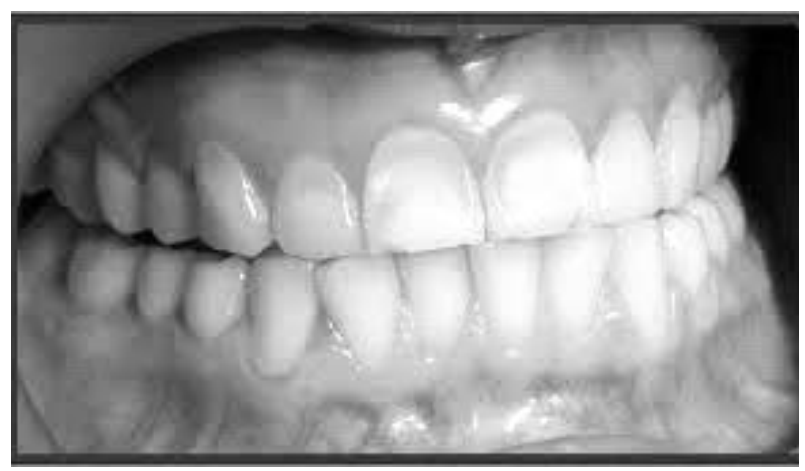

Рис. 3. Руйнування емалі центральних та латеральних різців на верхній щелепі, що охоплює значну частину коронки зуба. 
Хворі відзначали слабку гіперестезію лише на початку патологічного процесу. Електроодонтометрія пульпи становить 25 - 30 мкА. Відсутність больового симптому призводить до запізнілого зверненням пацієнтів до лікаря. У всіх хворих відмічають гіпосалівацію, що переходить у ксеростомію $[8,11]$.

Виявлені ознаки характеризуються активним дистрофічних процесом, що проявляється в одних випадках оголенням коренів зубів, особливо з вестибулярної і щічної поверхонь, у інших, уражень - близьких до ерозії. Резорбція міжзубних перетинок і альвеолярної кістки проходить рівномірно. У тих й інших варіантах усі процеси проходять із мінімальними ознаками запалення. Рентгенологічний малюнок зуба й альвеолярної кістки нечіткий, м'який, прозорий, що свідчить про гіпомінералізацію. На більшості зубів і їх коренях видно ніші, що відповідають ділянкам некрозу, різної форми і розміру $[2,12]$.

Аані клінічного та біохімічного аналізів крові без особливих відхилень. Проте слід відзначити сповільнений час згортання крові (3 хв 25 с - 3 хв 55 с). Тому при хірургічних втручаннях необхідна попередня підготовка таких пацієнтів. Аіагностика таких уражень тяжка і вимагає особливого підходу до лікування [10, 15].

лікування буває як місцевим, так і загальним. Загальне лікування включає призначення антиоксидантних препаратів, препаратів кальцію не менше 3 - 4-місячних курсів на рік. Необхідне введення препаратів, що містять макро- і мікроелементи (натрій, залізо, кальцій, мідь, калій, марганець, магній, цинк, фросфор, селен), вітаміни - A, B $, B_{2}, B_{6}, B_{12}$ E $[11,13]$.

Місцеве лікування на І етапі передбачає видалення некротизованих і нежиттєздатних тканин зуба з подальшою їх ремінералізацією шляхом щоденних 2-3-кратних аплікацій ремпрепаратів, електрофорезу гліцерофосфрату кальцію, полоскань і зрошень порожнини

\section{Список літератури}

1. Безвушко Е. В. Лікування системної гіпоплазії емалі / Е. В. Современная стоматология . - 2010. - № 5. C. $59-60$.

2. Бєліков О. Б. Поширеність некаріозних уражень твердих тканин зубів серед студентської молоді та рота зубними еліксирами, що містять вітаміни, антиоксиданти, мікроелементи, антисептики. Через 1 - 2 місяці переходять до вибіркового лікування окремих зубів. При цьому спочатку слід обмежитися тимчасовим пломбуванням порожнин із застосуванням кальцієвмісних прокладок терміном на $1-2$ місяці з метою утворення ремінералізованої зони дентину. I лише потім завершити лікування постійними пломбами з склоіономерних цементів. Таку тактику слід застосовувати навіть при пломбуванні кореневих каналів [12, 14].

Хворобу легше попередити, ніж лікувати, тому при щоденній роботі з комп'ютером слід Аотримуватися санітарних норм:

- площа робочого місця не повинна бути меншою ніж 6 м² при мінімальному обсязі всього приміщення 20-24 $\mathrm{M}^{2}$;

- природне освітлення повинно бути зліва;

- при розміщенні в робочому приміщенні 2 комп'ютерів і більше повинні бути дотримані відстані між відеомоніторами - 2 м при спрямованості екранів в один бік;

- працюючий повинен знаходитися віА екрана монітора на відстані 0,6-0,7 м;

- через кожні 2 год роботи необхідна перерва по 15 - 20 хв із провітрюванням приміщення;

- загальна тривалість роботи за комп'ютером, включаючи перерви, не повинна перевищувати 6 годАля дорослих і не більше 3-4 год Аля дітей і піАлітків.

Поряд з цим, особам, які постійно і часто працюють за комп'ютерами, слід рекомендувати деякі профілактичні заходи:

- прийом полівітамінів у зимовий і весняний періоди;

- застосування антиоксидантів;

- прийом кальцієвмісних препаратів;

- щоденний догляд за зубами з використанням фторвмісних зубних паст.

Все це в цілому дозволить уникнути можливого ураження зубів і сприятливо відіб'ється на організмі. причинно-наслідкові зв'язки їх виникнення / О. Б. Бєліков, Р. А. Бучок// Буковинський медичний вісник. - 2012. - T. 16, № 4 (64).

3. Белоклицкая Г. Ф. Некариозные поражения твердых тканей зубов / Г.Ф. Белоклицкая // Мистецтво лікування. - 2006. - № 9. - С . 88-90. 
4. Калінін В. Компьютеры. Некроз. Зубные болезни / В. Калінін // Медична сестра. - 2006. - № 4. C. $19-21$.

5. Кострюков А. А. Применение хлоргексидинсодержащего геля «Пародиум» в сочетании с медицинским клеем МК-8 в комплексном лечении пародонтита / А. А. Кострюков, Е. Н. Новикова, А. А. Амитриева // Пародонтология. - 2004. - № 1 (30). - http:// www.parodont.ru/free/30/art8.shtml

6. Комп'ютер добрався до зубів - new-s.com.ua/news/ .../news_asorti_konpjuter_dobravsja_do_zybiv.htmlэ 7. Кріль I. А. Поширеність системної гіпоплазії емалі у школярів м. Івано-Франківська / I. А. Кріль, М. М. Рожко // Гал. лікар. вісник. - 2011. - Т. 18, № 2. - C. $53-55$.

8. Некариозные поражения. Компьютерный некроз. лечение и профилактика sir35.narod.ru/Tibet/ zyb1.htmэ

9. Коцерова $\lambda$. М. Здоров'я від А до Я : наукові статті некаріозних уражень. Комп'ютерний некроз. Аікування і профілактика стоматологічних захворювань - mediclab.com.ua
10. Макеева И. М. Клиническая оценка эффективности ентингерметизирующего раствора при лечении некариозных поражений зубов - клиновидного дефекта и эрозии твердых тканей зуба / И. М. Макеева, Н. Н. ААян // Клин. стоматол. - 2008. - № 3. C. $82-85$.

11. Нова хвороба - комп'ютерний некроз зубів vidgolos.com/838-nova-khvoroba-kompjuterni. vidgolos.com/838-nova-khvoroba-kompjuterni

12. Олейник Е. А. Аинамическое исследование состояния зубной эмали у пациентов с гипоплазией / Е. А. Олейник // Стоматология детского возраста и профилактика. - 2008. - № 1. - С. 42- 43.

13. Полевська $\lambda$. І. Від комп'ютера зуби псуються, а збережуть їх пасти-«чистильники» / ^.І.Полевська - archive.wz.lviv.ua/articles/9594э

14. Просиджування за комп'ютером позначається на зубах. - megasite.in.ua/47070-prosidzhuvannya-zakomp-yuterom-poznachaehts.

15. Ткаченко I. М. Етіологічні чинники в розвитку патологічної стертості емалі зубів / I. М. Ткаченко // Вісн. пробл. біол. імед. - 2011. - Вип. 2, Т. 1. C. $48-50$. 